\title{
Surgical Treatment for Stress Urinary Incontinence in Women: A Systematic Review and Meta-analysis
}

\section{Tratamento cirúrgico da incontinência urinária de esforço em mulheres: revisão sistemática e metanálise}

\author{
Letícia Maria de Oliveira ${ }^{1}$ Marcia Maria Dias ${ }^{1}$ Sérgio Brasileiro Martins ${ }^{1}$ jorge Milhem Haddad ${ }^{2}$ \\ Manoel João Batista Castello Girão ${ }^{1}$ Rodrigo de Aquino Castro ${ }^{1}$
}

${ }^{1}$ Department of Gynecology, Paulista School of Medicine,
Universidade Federal de São Paulo, São Paulo, SP, Brazil
${ }^{2}$ Department of Gynecology, Faculty of Medicine, Universidade de
São Paulo, São Paulo, SP, Brazil

Rev Bras Ginecol Obstet 2018;40:477-490.

\begin{abstract}
Address for correspondence Letícia Maria de Oliveira, MD, PhD, Rua Botucatu, 740, Vila Clementino, São Paulo, SP, 04023-062, Brazil (e-mail: leticia_maria@uol.com.br).
\end{abstract}

\begin{abstract}
Keywords

- stress urinary incontinence

- Burch surgery

- midurethral sling

- pubovaginal sling

- meta-analysis

Objective To compare surgical treatments for stress urinary incontinence in terms of efficiency and complications.

Data Sources We searched the MEDLINE and COCHRANE databases using the terms stress urinary incontinence, surgical treatment for stress urinary incontinence and sling.

Selection of Studies Forty-eight studies were selected, which amounted to a total of 6,881 patients with scores equal to or higher than 3 in the Jadad scale.

Data Collection Each study was read by one of the authors, added to a standardized table and checked by a second author. We extracted data on intervention details, follow-up time, the results of treatment and adverse events.

Data Synthesis Comparing retropubic versus transobturator slings, the former was superior for both objective (odds ratio [OR], 1.27; 95\% confidence interval [CI], 1.05-1.54) and subjective (OR, 1.23; $95 \% \mathrm{Cl}, 1.02-1.48)$ cures. Between minislings versus other slings, there was a difference favoring other slings for subjective cure $(\mathrm{OR}, 0.58 ; 95 \% \mathrm{Cl}, 0.39$ 0.86). Between pubovaginal sling versus Burch surgery, there was a difference for both objective (OR, 2.04; 95\% Cl, 1.50-2.77) and subjective (OR, 1.64; 95\% Cl, 1.10-2.44) cures, favoring pubovaginal sling. There was no difference in the groups: midurethral slings versus Burch, pubovaginal sling versus midurethral slings, transobturator slings, minislings versus other slings (objective cure). Retropubic and pubovaginal slings are more retentionist. Retropubic slings have more bladder perforation, and transobturator slings, more leg and groin pain, neurological lesion and vaginal perforation.

Conclusion Pubovaginal slings are superior to Burch colposuspension surgery but exhibit more retention. Retropubic slings are superior to transobturator slings, with more adverse events. Other slings are superior to minislings in the subjective aspect. There was no difference in the comparisons between midurethral slings versus Burch colposuspension surgery, pubovaginal versus midurethral slings, and inside-out versus outside-in transobturator slings.
\end{abstract}

received

March 6, 2018

accepted

May 22, 2018
DOI https://doi.org/

10.1055/s-0038-1667184. ISSN 0100-7203.
Copyright (e 2018 by Thieme Revinter

Publicações Ltda, Rio de Janeiro, Brazil
License terms

(c) (1) 


\section{Resumo}

\section{Palavras-chave}

- incontinência urinária de esforço

- cirurgia de Burch

- sling de uretra média

- sling pubovaginal

- metanálise
Objetivo comparar tratamentos cirúrgicos para incontinência urinária de esforço (IUE), quanto à eficiência e complicações, por meio de revisão sistemática seguida de metanálise.

Fonte dos dados fizemos busca nas bases de dados MEDLINE e COCHRANE, utilizando os termos stress urinary incontinence, surgical treatment for stress urinary incontinence e sling.

Seleção dos estudos Selecionamos 48 estudos, totalizando 6.881 pacientes com pontuação igual ou maior do que 3 na escala de Jadad.

Coleta de dados Cada estudo foi lido por um autor, colocado em tabela, e checado por outro autor. Extraímos dados como detalhes das intervenções, tempo de seguimento, resultados do tratamento e eventos adversos.

Síntese dos dados Não houve diferença nas comparações: sling de uretra média versus cirurgia de Burch, quanto às curas objetiva (razão de chances [RC]: 1,29; intervalo de confiança de 95\% [IC95\%]: 0,76-2,20) e subjetiva (RC: 1,16; IC95\%: 0,672,00); sling de uretra média transobturatório outside-in versus inside-out quanto às curas objetiva (RC: 0,78; IC95\%: 0,45-1,35) e subjetiva (RC: 0,83; IC95\%: 0,58-1,18); sling pubovaginal e de uretra média quanto à cura objetiva (RC: 1,64; IC 95\%: 0,52-5,15). Comparando sling retropúbico com transobturatório, o retropúbico foi superior quanto às curas objetiva (RC: 1,27 ; IC95\%: 1,05-1,54) e subjetiva (RC: 1,23; IC95\%: 1,02-1,48). Entre minislings e outros slings, houve diferença favorável a outros slings quanto à cura subjetiva (RC: 0,58 ; IC95\%: $0,39-0,86$ ) mas não quanto à cura objetiva (RC: 0,72 ; IC95\%: 0,47-1,10). No grupo sling pubovaginal e Burch, houve diferença quanto à cura objetiva (RC: 2,04; IC95\%: 1,50-2,77) e subjetiva (RC: 1,64; IC95\%: 1,10-2,44). Slings de uretra média apresentam mais erosão, enquanto a cirurgia de Burch tem mais complicações na ferida operatória e infecção do trato urinário. Slings retropúbicos e pubovaginais são mais retencionistas. Slings retropúbicos estão mais associados a lesão vascular, hematomas e perfuração vesical, e transobturatórios, à dor na perna e virilha, lesão neurológica e perfuração vaginal.

Conclusão Slings pubovaginais são superiores à cirurgia de Burch, porém mais retencionistas. Slings retropúbicos são superiores aos transobturatórios, embora tenham mais eventos adversos. Outros slings são superiores aos minislings em relação ao aspecto subjetivo. Não houve diferença nas comparações entre slings de uretra média e cirurgia de Burch, slings pubovaginais, transobturatórios inside-out e inside-in.

\section{Introduction}

Stress urinary incontinence (SUI) is defined by the International Continence Society (ICS) as the involuntary loss of urine during physical exertion, such as while coughing, sneezing, laughing or running. ${ }^{1}$ This condition affects 13 to $46 \%$ of women at a young age, reaching even higher rates if we consider postmenopausal women, ${ }^{2-4}$ with severe repercussions for quality of life as it affects physical, sexual, emotional and social aspects. ${ }^{3}$

Several clinical and surgical options have been used for the treatment of SUI. Our review does not take into account clinical treatments. For surgical treatments, several techniques are described, including the more commonly known: Burch colposuspension, either abdominal or laparoscopic, pubovaginal slings, retropubic and transobturator midurethral slings, and single-incision slings (minislings).
Burch colposuspension and pubovaginal slings are considered the "gold standard" for surgical treatment of SUI. Since described in 1996 by Ulmsten et al, $^{5}$ the synthetic tension-free vaginal tape (TVT) sling has been used in a growing and widespread manner throughout the world. Even though this technique has achieved high cure rates in the mid and long term, ${ }^{6,7}$ important complications, such as bladder perforation, retropubic hematomas and voiding dysfunction have also been reported. ${ }^{8,9}$ In an attempt to minimize these complications, in 2001, Delorme ${ }^{10}$ described a new technique involving the placement of a synthetic mesh under the middle urethra through the transobturator route from the thigh to the vagina (transobturator tape outside-in [TOT]). In 2003, de Leval ${ }^{11}$ introduced a modification to the technique, proposing insertion of the mesh toward the opposite direction, from the vagina to the thigh (transobturator tape inside-out [TVT-O]). Both slings placed by transobturator approach have shown 
high rates of cure. ${ }^{10,11}$ However, several researchers describe thigh pain as a main complication. ${ }^{12}$ Thus, to further reduce complication rates, single-incision slings, or minislings, were introduced with objective and subjective cure rates very close to those obtained with TVT and TOT at mid-term follow-up, according to a meta-analysis published in $2014 .^{13}$

The literature is vast regarding surgical procedure success rates for treating female SUI, but the quality of many studies is questionable. In an attempt to clarify the best technique for each case, we proposed this systematic review followed by meta-analysis, based on good quality randomized trials, comparing objective and subjective results, and complications.

\section{Study Search}

We searched the MEDLINE and Cochrane Central Register for Controlled Trials databases from January 1990 to December 2016. We used the following keywords to search for studies: stress urinary incontinence, surgical treatment for stress urinary incontinence, sling, pubovaginal sling, retropubic sling, transobturator sling, minisling, Burch colposuspension. The search was limited to comparative and randomized studies. We included only human studies written in English, French and Spanish. We found some few articles in other languages that did not fill the Jadad criteria. The articles listed in the search results were only used when the full text was available. The authors of the studies were not contacted.

Three of the authors (LMO, MMD, SBM) in our metaanalysis did the initial research of all studies independently. After reading the titles and abstracts, we read the full text of the studies considered potentially eligible, which were later included in a standardized table for data extraction if the eligibility criteria were met.

\section{Study Selection}

We selected the relevant studies by applying the three-point questionnaire that form the basis he Jadad scale. Each question was to be answered with either a yes or a no. Each yes would score a single point, each no zero points The questions were as follows: Was the study described as randomized?; Was the study described as double blind? and Was there a description of withdrawals and dropouts? To receive the corresponding point, an article should describe the number of withdrawals and dropouts, in each of the study groups, and the underlying reasons. Additional points were given if: The method of randomization was described in the paper, and that method was appropriate or The method of blinding was described, and it was appropriate. Points would be deducted if: The method of randomization was described but was inappropriate. or The method of blinding was described, but was inappropriate. A clinical trial could therefore receive a Jadad score between zero and five. ${ }^{14}$ Studies with a score lower than three points on this scale were excluded.

To evaluate the results, we included randomized, comparative studies with a minimum of 12 months of follow-up, comparing 2 or more sling procedures or a sling procedure with Burch colposuspension surgery, performed on women over 18 years of age with SUI diagnosed by clinical history, stress test and/or urodynamic evaluation or pad test. Studies that included mixed urinary incontinence (MUI), predominantly SUI, and intrinsic sphincteric deficiency (ISD) were also admitted.

Whenever there were three arms in the study, we compared two arms at a time. For the analysis of side effects, we used only the studies that were selected for the meta-analysis.

The types of slings included were midurethral slings (retropubic and transobturator), pubovaginal slings (synthetic and autologous) and minislings.

Studies comparing the Burch technique with any other non-sling surgical modality to treat SUI were not included.

Studies using materials that were withdrawn from the market were excluded from our review, as were studies comparing different products by equal routes.

The results of interest in the studies analyzed were divided into six categories: objective or subjective cure, perioperative results, quality of life and satisfaction questionnaires, sexual function and adverse events ( $\mathbf{- T a b l e ~} \mathbf{1}$ ). However, only meta-analytic studies were performed for objective or subjective cure and adverse events.

\section{Data Extraction and Assessment}

Each of the included studies was read by one of the authors, and the data were extracted and inserted in a previously standardized table. Then, each study was checked by a second author. Discrepancies were resolved by consensus among three of the authors. We extracted data on study characteristics, details of interventions, follow-up time, results of treatment and adverse events.

\section{Data Synthesis and Analysis}

We compared midurethral sling versus Burch surgery, pubovaginal sling versus Burch surgery, pubovaginal sling versus midurethral sling, retropubic versus transobturator midurethral sling, transobturator outside-in midurethral sling versus transobturator inside-out and minisling versus other slings.

Whenever we found two or more randomized studies comparing the same surgical techniques in relation to the same outcomes and adverse events, we resorted to a metaanalysis, which is the most adequate statistical technique to combine results from different studies. ${ }^{58,59}$

It is natural to think of using the fixed-effect model, which assumes that the effect of interest is the same in all included studies. However, the studies are not identical regarding effect of interest and are therefore considered heterogeneous. Thus, to verify the existence of heterogeneity, we used the Cochran $\mathrm{Q}$ test and the $\mathrm{I}^{2}$ statistic by Higgins and Thompson. ${ }^{60}$

The null hypothesis of the Cochran Q test asserts that the studies are homogeneous. A high $Q$ value indicates that there is great heterogeneity. However, the $p$-value associated with the test indicates whether the heterogeneity is 
Table 1 Randomized controlled trials included in the systematic review

\begin{tabular}{|c|c|c|c|c|c|c|c|c|c|c|c|}
\hline Study & Intervention (1) & Comparator (2) & $\mathrm{N}(1)$ & $N(2)$ & Follow-up & OC & SC & $\mathrm{PO}$ & $\mathrm{AE}$ & QoL & SF \\
\hline \multicolumn{12}{|l|}{ MUS versus Burch } \\
\hline Bai et al. $(2005)^{15}$ & Retropubic (TVT) & Burch & 31 & 33 & 1 year & $x$ & & & $x$ & & \\
\hline Jelovsek et al. $(2008)^{16}$ & Retropubic (TVT) & Burch L & 25 & 28 & 65 months & & $\mathrm{x}$ & & & $x$ & \\
\hline Liapis et al. (2002) ${ }^{17}$ & Retropubic (TVT) & Burch & 35 & 36 & 2 years & $x$ & & $\mathrm{x}$ & $\mathrm{x}$ & & \\
\hline Paraiso et al. $(2004)^{18}$ & Retropubic (TVT) & Burch lap & 31 & 32 & 21 months & $x$ & & $x$ & $\mathrm{x}$ & $x$ & \\
\hline Persson et al. $(2002)^{19}$ & Retropubic (TVT) & Burch lap & 37 & 31 & 1 year & $x$ & $x$ & $x$ & $x$ & & \\
\hline Ward et al. $(2008)^{20}$ & Retropubic (TVT) & Burch & 72 & 49 & 5 years & $x$ & & $x$ & $x$ & $x$ & $x$ \\
\hline Valpas et al. $(2015)^{21}$ & Retropubic (TVT) & Burch lap & 51 & 40 & 5 years & $x$ & $x$ & $x$ & $x$ & $x$ & \\
\hline \multicolumn{12}{|l|}{ PVS versus Burch } \\
\hline Albo et al. $(2007)^{22}$ & PVS (autologous fascia) & Burch & 326 & 329 & 2 years & $x$ & $x$ & $x$ & $x$ & $x$ & \\
\hline Bai et al. $(2005)^{15}$ & PVS (autologous fascia) & Burch & 28 & 33 & 1 year & $x$ & & & $x$ & & \\
\hline Culligan et al. $(2003)^{23}$ & PVS (Gore-Tex) & Burch & 13 & 15 & 73 months & $x$ & $x$ & $x$ & $x$ & & \\
\hline \multicolumn{12}{|l|}{ PVS versus MUS } \\
\hline Bai et al. $(2005)^{15}$ & PVS (autologous fascia) & Retropubic (TVT) & 28 & 31 & 1 year & $x$ & & & $x$ & & \\
\hline Guerrero et al. $(2010)^{24}$ & PVS (autologous fascia) & Retropubic (TVT) & 67 & 69 & 1 year & & $x$ & $x$ & $x$ & $x$ & \\
\hline $\begin{array}{l}\text { Sharifiaghdas and } \\
\text { Mortazavi }(2008)^{25}\end{array}$ & PVS (autologous fascia) & Retropubic (TVT) & 25 & 36 & 40 months & $x$ & $x$ & $x$ & $x$ & $x$ & \\
\hline \multicolumn{12}{|l|}{ TVT versus TOT } \\
\hline Angioli et al. $(2010)^{26}$ & TVT & TVT-O & 35 & 37 & 5 years & $x$ & $x$ & $x$ & $x$ & $x$ & $x$ \\
\hline Araco et al. $(2008)^{27}$ & TVT & TVT-O & 108 & 109 & 1 year & $x$ & & $x$ & $x$ & $x$ & \\
\hline Barber et al. $(2008)^{28}$ & TVT & Monarc & 79 & 71 & 1 year & $x$ & $x$ & $x$ & $x$ & $x$ & $x$ \\
\hline Costantini et al. $(2016)^{29}$ & TVT & Obtape & 40 & 47 & 5 years & $\mathrm{x}$ & $\mathrm{x}$ & $\mathrm{x}$ & $\mathrm{x}$ & $\mathrm{x}$ & \\
\hline Deffieux et al. $(2010)^{30}$ & TVT & TVT-O & 67 & 65 & 2 years & $x$ & $x$ & $x$ & $\mathrm{x}$ & $\mathrm{x}$ & $x$ \\
\hline Freeman et al. $(2011)^{31}$ & TVT & Monarc & 85 & 95 & 1 year & & $x$ & $x$ & $x$ & $x$ & $x$ \\
\hline Karateke et al. $(2009)^{32}$ & TVT & TVT-O & 81 & 83 & 14 months & $x$ & $x$ & $x$ & $\mathrm{x}$ & & \\
\hline Krofta et al. $(2010)^{33}$ & TVT & TVT-O & 141 & 147 & 1 year & $x$ & $x$ & $x$ & $x$ & $x$ & $x$ \\
\hline Laurikainen et al. $(2014)^{34}$ & TVT & TVT-O & 131 & 123 & 5 years & $x$ & $x$ & $x$ & $x$ & & \\
\hline Lee et al. $(2007)^{35}$ & TVT & TVT-O & 60 & 60 & 13 months & $x$ & $\mathrm{x}$ & $x$ & $\mathrm{x}$ & $x$ & \\
\hline Richter et al. $(2010)^{36}$ & TVT & TVT-O/Monarc & 291 & 292 & 1 year & $x$ & $x$ & $x$ & $x$ & $x$ & $x$ \\
\hline Rinne et al. $(2008)^{37}$ & TVT & TVT-O & 134 & 131 & 1 year & & $x$ & $x$ & $x$ & $\mathrm{x}$ & \\
\hline Ross et al. $(2009)^{38}$ & Advantage & Obtrix & 95 & 86 & 1 year & $x$ & $x$ & $x$ & $x$ & $x$ & $x$ \\
\hline Ross et al. $(2016)^{39}$ & Advantage & Obtrix & 74 & 66 & 5 years & $x$ & & & $x$ & $x$ & $x$ \\
\hline Scheiner et al. $(2012)^{40}$ & TVT & Monarc & 65 & 34 & 1 year & $x$ & $x$ & $x$ & $x$ & $x$ & $x$ \\
\hline Scheiner et al. $(2012)^{40}$ & TVT & TVT-O & 65 & 37 & 1 year & $x$ & $x$ & $x$ & $x$ & $x$ & $x$ \\
\hline Schierlitz et al. (2012) ${ }^{41}$ & TVT & TVT-O & 72 & 75 & 3 years & $x$ & $x$ & $\mathrm{x}$ & $x$ & $x$ & \\
\hline Teo et al. $(2011)^{42}$ & TVT & TVT-O & 41 & 29 & 1 year & $\mathrm{x}$ & $x$ & $x$ & $\mathrm{x}$ & $x$ & \\
\hline Wadie and El-Hefnawy (2013) & TVT & TOT (Aris) & 36 & 35 & 2 years & $x$ & $x$ & $x$ & $x$ & $x$ & \\
\hline Wang et al. $(2010)^{44}$ & TVT & TOT & 70 & 70 & 1 year & $x$ & $x$ & $x$ & $x$ & $x$ & \\
\hline Wang et al. $(2009)^{45}$ & TVT & TVT-O & 35 & 30 & 3 years & $x$ & & $x$ & $\mathrm{x}$ & & \\
\hline Zhang et al. (2016) & TVT & TVT-O & 58 & 62 & 95 months & $x$ & $x$ & $x$ & $x$ & $x$ & \\
\hline \multicolumn{12}{|l|}{ TOT versus TVT-O } \\
\hline Abdel-Fattah et al. $(2010)^{47}$ & TOT (Aris) & TVT-O & 152 & 147 & 1 year & $x$ & $x$ & & $x$ & $x$ & $x$ \\
\hline Houvert et al. (2009) ${ }^{48}$ & TOT (Monarco) & TVT-O & 86 & 75 & 38 months & & $x$ & $x$ & $x$ & $x$ & $x$ \\
\hline Liapis et al. $(2008)^{49}$ & TOT (Monarc) & TVT-O & 53 & 61 & 1 year & $x$ & $x$ & $\mathrm{x}$ & $\mathrm{x}$ & & \\
\hline Park and Kim (2012) & Monarc & TVT-O & 35 & 39 & 3 years & $x$ & $x$ & $x$ & $x$ & & \\
\hline Scheiner et al. $(2012)^{40}$ & Monarc & TVT-O & 34 & 37 & 1 year & $x$ & $x$ & $x$ & $x$ & $x$ & $x$ \\
\hline \multicolumn{12}{|l|}{ Minisling versus any sling } \\
\hline Basu and Duckett (2013) $)^{51}$ & Miniarc & $\begin{array}{l}\text { Retropubic } \\
\text { (Advantage) }\end{array}$ & 38 & 33 & 3 years & & $x$ & $x$ & $x$ & $x$ & \\
\hline
\end{tabular}


Table 1 (Continued)

\begin{tabular}{|c|c|c|c|c|c|c|c|c|c|c|c|}
\hline Study & Intervention (1) & Comparator (2) & $N(1)$ & $N(2)$ & Follow-up & OC & SC & PO & $\mathrm{AE}$ & QoL & SF \\
\hline \multicolumn{12}{|l|}{ MUS versus Burch } \\
\hline Djehdian et al. $(2014)^{52}$ & Ophira & TOT (Unitape) & 69 & 61 & 1 year & $x$ & $x$ & $x$ & $x$ & $x$ & \\
\hline Gaber et al. $(2016)^{53}$ & Contasure-Needleless & TVT-O & 70 & 70 & 1 year & $x$ & $x$ & $x$ & $x$ & $x$ & \\
\hline Gaber et al. $(2016)^{53}$ & EFA & TVT-O & 69 & 70 & 1 year & $x$ & $x$ & $x$ & $x$ & $x$ & \\
\hline Jurakova et al. $(2016)^{54}$ & Ophira & TVT-O & 44 & 46 & 1 year & $x$ & $x$ & $x$ & $x$ & $x$ & \\
\hline Lee et al. $(2015)^{55}$ & Miniarc & TOT (Monarc) & 103 & 103 & 1 year & $x$ & $x$ & $x$ & $x$ & & \\
\hline Schellart et al. $(2016)^{56}$ & Miniarc & TOT (Monarc) & 73 & 72 & 2 years & $x$ & $x$ & $\mathrm{x}$ & $x$ & $x$ & \\
\hline Sivaslioglu et al. $(2012)^{57}$ & TFS & TOT (I-STOP) & 36 & 36 & 5 years & $x$ & $x$ & $x$ & $x$ & & \\
\hline
\end{tabular}

Abbreviations: EFA, endopelvic free anchor; MUS, midurethral sling; PVS, pubovaginal sling; TFS, tissue fixation system; TOT, transobturator tape; TVT, tension-free vaginal tape; TVT-O, tension-free vaginal tape obturator.

significant or not, if different from zero. A deficiency of this test is its low power when the meta-analysis is made up of a small number of studies. The $\mathrm{I}^{2}$ statistic by Higgins and Thompson ${ }^{60}$ derives from Cochran $Q$ test and the number of studies involved in the meta-analysis. The $\mathrm{I}^{2}$ statistic can range from minus zero to $100 \%$. Negative values are considered zero. The $p$-value of $\mathrm{I}^{2}$ is equivalent to the $p$-value of Cochran $Q$ test. $^{60}$

Higgins and Thompson ${ }^{60}$ suggest a scale where a value of $\mathrm{I}^{2}$ close to zero indicates that there is no heterogeneity between studies, while a value close to $25 \%$ indicates low heterogeneity, $50 \%$ indicates moderate heterogeneity, and more than $75 \%$ indicates high heterogeneity. ${ }^{60}$

Just as in the option of effect measure, we used odds ratio (OR). We used the Mantel-Haenszel method because most of the studies included had small sample sizes. However, for certain effects, some studies presented zero events in at least one of the comparison groups, and in these cases, we used the Peto method. ${ }^{61}$

We used the Cochrane Collaboration's Review Manager software (RevMan, The Nordic Cochrane Centre, The Cochrane Collaboration, Copenhagen, Denmark), version 5.3, to conduct our meta-analysis.

\section{Results}

The searches performed on MEDLINE and Cochrane resulted in 2,942 abstracts. After reading the titles and abstracts, 2,707 results were excluded and there were 235 remaining, whose texts were read in full. The study search flow is detailed in - Fig. 1. Next, we found 48 articles that met the inclusion criteria in the meta-analysis, totaling 6,881 patients, - Table 1.

\section{Midurethral Sling versus Burch}

For this comparison, we found 7 studies that analyzed 531 patients (282 in the midurethral sling group and 249 in the Burch surgery group). All studies used the Gynecare TVT retropubic sling (Ethicon Inc., Somerville, New Jersey, USA), compared with laparotomy ${ }^{17}$ or laparoscopic ${ }^{16,21}$ Burch surgery. Of the studies included in this group, six yielded objective cure results, ${ }^{15,17-21}$ while three presented data on subjective cure, ${ }^{16,19,21}$ and six presented data on adverse events, with the exception of Jelovsek et al (2008). ${ }^{16}$

The following tests were used to assess objective cure: pad test, ${ }^{17,19,20}$ stress test ${ }^{15,21}$ and urodynamic evaluation. ${ }^{17-20}$

For subjective cure, the authors used: satisfaction questionnaire, ${ }^{19}$ visual analog scale(VAS), ${ }^{18,21}$ Urinary Incontinence Severity Score (UISS), ${ }^{21}$ Patients Global Impression of Improvement(PGII), ${ }^{16,21}$ Incontinence Severity Index (ISI), ${ }^{16}$ Urogenital Distress Inventory 6 (UDI-6), ${ }^{16,18}$ Incontinence Impact Questionnaire 7 (IIQ-7), ${ }^{16,18}$ Bristol Female Lower Urinary Tract Symptoms (BFLUTS) ${ }^{20}$ and Short Form-36 (SF-36). ${ }^{20}$

The meta-analysis showed no significant difference regarding objective cure in the comparison between midurethral sling and Burch surgery (OR, 1.29; 95\% confidence interval [CI], 0.76-2.20) - Fig. 2. Moreover, no significant difference was found for subjective cure (OR, 1.16; 95\% CI, 0.67-2.00) - Fig. 3.

Regarding adverse events, we observed that the midurethral slings had higher rates of erosion (OR, 5.98; 95\% CI, 1.16-30.67) and bladder perforation (OR, 2.74; 95\% CI, 1.24-6.03), while Burch surgery had higher rates of surgical wound complications (OR, 0.30; 95\% CI, 0.10-0.90) and urinary tract infection (UTI) (OR, 0.30; 95\% CI, 0.14-0.63). There was no significant difference between these procedures in relation to the following adverse events: postoperative pain, hematoma, need for further surgery due to erosion or urinary retention, urinary retention for less than 6 weeks and overactive bladder. Adverse events such as blood loss, retention lasting for longer than 6 weeks, transfusion, de novo urgency and vaginal perforation were described in a single study, and therefore did not justify a meta-analysis.

\section{Pubovaginal Sling versus Burch Surgery}

For this comparison, we found 3 studies with high-quality evidence including 744 patients; 367 in the pubovaginal sling group and 377 in the Burch group. Two studies used autologous rectus fascia ${ }^{15,22}$ and one study used a synthetic sling. ${ }^{23}$ The three were compared with laparotomy Burch colposuspension. All the studies in this group presented results for objective cure and adverse events, while only two showed data on subjective cure. ${ }^{22,23}$ To assess objective cure, the following tests were used: pad test ${ }^{22,23}$ and stress test. ${ }^{15,22,23}$ To assess subjective cure, the authors used: UDI and IIQ. ${ }^{22}$ 
482 Surgical Treatment for Stress Urinary Incontinence Oliveira et al.

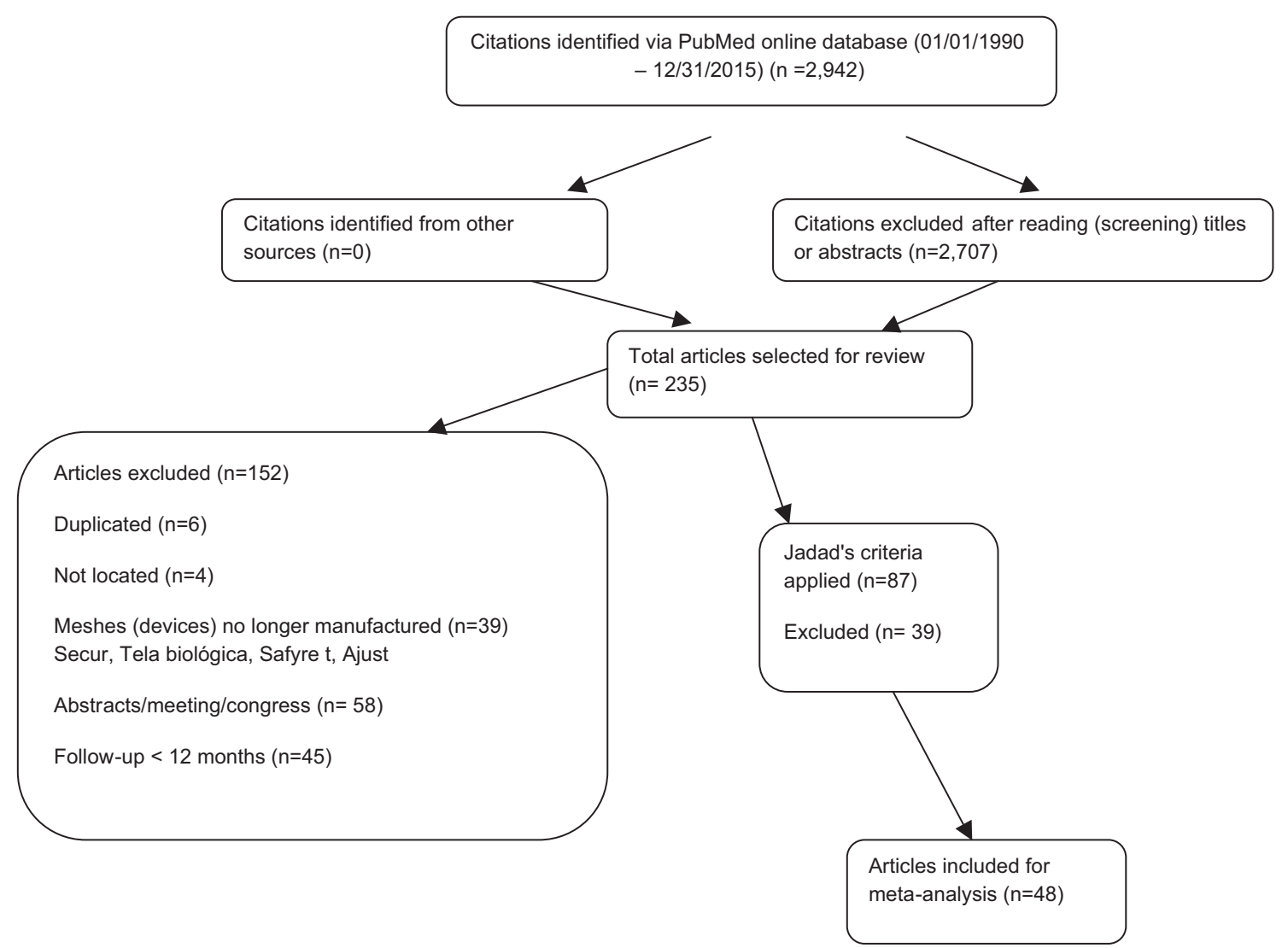

Fig. 1 Flowchart.

\begin{tabular}{|c|c|c|c|c|c|c|}
\hline \multirow[b]{2}{*}{ Study or Subgroup } & \multicolumn{2}{|c|}{ Midurethral sling } & \multicolumn{2}{|c|}{ Burch surgery } & \multirow[b]{2}{*}{ Weight } & \multirow{2}{*}{$\begin{array}{c}\text { Odds Ratio } \\
\text { M-H, Fixed, } 95 \% \mathrm{Cl}\end{array}$} \\
\hline & Events & Total & Events & Total & & \\
\hline Bai et al, 2005 & 27 & 31 & 29 & 33 & $15.3 \%$ & $0.93[0.21,4.10]$ \\
\hline Liapis et al, 2002 & 30 & 35 & 31 & 36 & $18.4 \%$ & $0.97[0.25,3.69]$ \\
\hline Paraiso et al, 2004 & 30 & 31 & 26 & 32 & $3.5 \%$ & $6.92[0.78,61.32]$ \\
\hline Person et al, 2002 & 33 & 37 & 27 & 31 & $13.4 \%$ & $1.22[0.28,5.35]$ \\
\hline Valpas et al, 2015 & 48 & 51 & 31 & 40 & $8.6 \%$ & $4.65[1.17,18.51]$ \\
\hline Ward et al, 2008 & 59 & 72 & 45 & 49 & $40.8 \%$ & $0.40[0.12,1.32]$ \\
\hline Total $(95 \%$ Cl) & & 257 & & 221 & $100.0 \%$ & $1.29[0.76,2.20]$ \\
\hline Total events & 227 & & 189 & & & \\
\hline $\begin{array}{l}\text { Heterogeneity: } \mathrm{Chi}^{2} \\
\text { Test for overall effec }\end{array}$ & $\begin{array}{l}64, d f=5 \\
=0.94(P\end{array}$ & $\begin{array}{l}=0.09) \\
.35)\end{array}$ & $1^{2}=48 \%$ & & & \\
\hline
\end{tabular}

Fig. 2 Objective cure: midurethral slings versus Burch surgery.

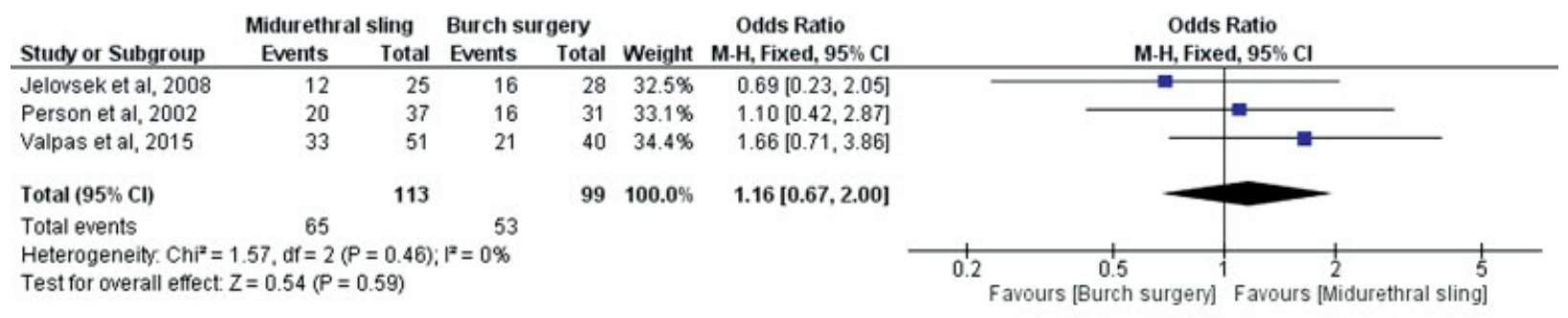

Fig. 3 Subjective cure: midurethral slings versus Burch surgery. 
The meta-analysis showed no statistically significant difference regarding objective cure in the comparison between pubovaginal slings and Burch colposuspension (OR, 2.04; 95\% CI, 1.50-2.77) (-Fig. 4).

Regarding subjective cure, the meta-analysis results showed a significant difference favoring pubovaginal slings over Burch colposuspension (OR, 1.64; 95\% CI, 1.10-2.44) (-Fig. 5).

Regarding adverse events, we observed that, according to the analysis, the patients returned to the operating room more often due to retention in the group of pubovaginal slings, showing statistical significance (OR, 7.95; 95\% CI, 3.34-18.94). Other complications were included in a single study, which precludes a meta-analytical comparison.

\section{Pubovaginal Sling versus Midurethral Sling}

For this comparison, we selected 3 studies including 256 patients, 120 in the pubovaginal sling group and 136 in the midurethral sling group. In all studies, autologous rectus fascia was used to construct a pubovaginal sling. For midurethral sling, all studies used retropubic TVT. Of the studies found in this group of analysis, two presented results on objective cure ${ }^{15}$ and only one showed subjective cure. ${ }^{24}$ To assess objective cure, the authors used: the pad test, ${ }^{25}$ stress test $^{15,25}$ and urodynamic evaluation. ${ }^{25}$ To analyze subjective cure, the authors used: the satisfaction test, ${ }^{24}$ BFLUTS $^{24}$ and IIQ. ${ }^{25}$ Regarding objective cure, the meta-analysis showed that there was no significant between-group difference (OR 1.64, 95\% CI: 0.52-5.15) (-Fig. 6). For subjective cure, there was no possibility of meta-analysis, since this variable was analyzed in one study only.

In this group, we observed that some adverse events were reported, such as bladder perforation, urinary retention for less than 6 weeks and return to the operating room due to urinary retention, although these were not significant between groups. Other complications, such as blood loss, transfusion, and de novo urgency were described in a single study, and therefore did not justify a meta-analysis.

\section{Retropubic Sling versus Transobturator Sling}

In this comparison group, we found 22 studies including 3,638 patients, 1,863 in the group treated with retropubic sling and 1,775 in the transobturator group. In most of them, the Gynecare TVT and TVT-O (Ethicon Inc., Somerville, New Jersey, USA) were compared. ${ }^{26,27,30,32-35,37,40-42,46,47}$ In the other studies, TVT and Monarc (American Medical Systems, Minnetonka, MN, USA) were compared. ${ }^{28,31,40,44}$ One study, by Richter et al (2010), ${ }^{36}$ compared TVT with TVT-O or Monarc. Ross et al $(2009,2016)^{38,39}$ used Advantage (retropubic) and Obtrix (transobturator) (both products made by Boston Scientific, Natick, MA, USA), and Wadie and ElHefnawy $(2013)^{43}$ compared TVT and Aris TOT (Coloplast, Minneapolis, MN, USA). Tension-free vaginal tape and Obtape (Mentor-Porgés, Le Plessis-Robinson, France) were compared by Costantini et al (2016). ${ }^{29}$

Of the studies found in this comparison group, only one $\mathrm{e}^{31}$ did not present results for objective cure. Six studies did not

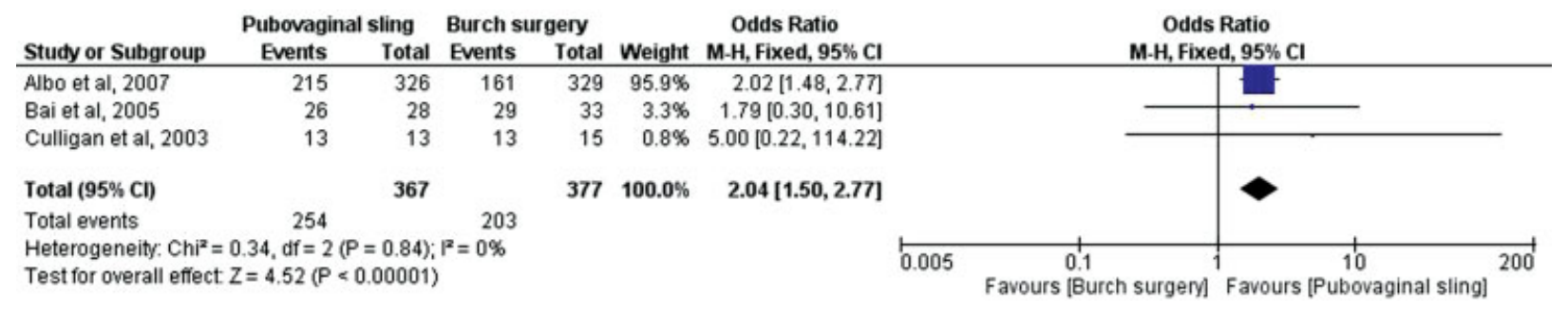

Fig. 4 Objective cure: Pubovaginal sling versus Burch surgery.

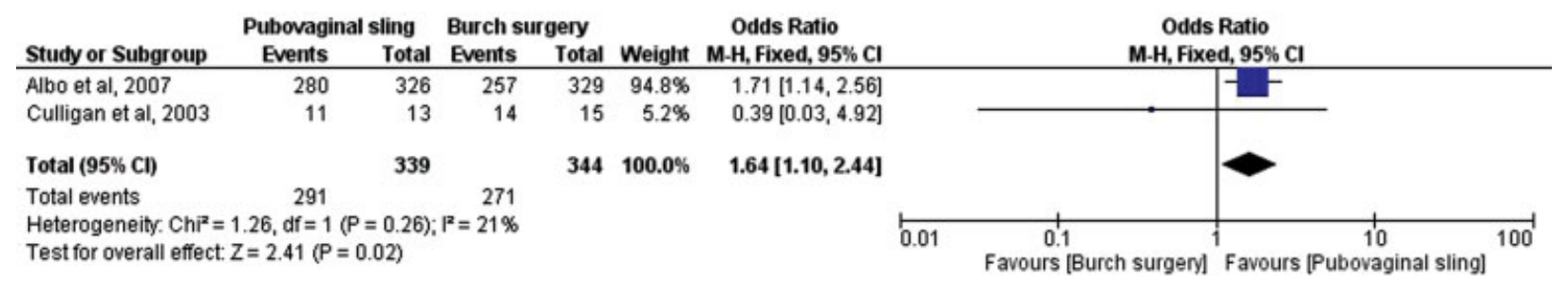

Fig. 5 Subjective cure: Pubovaginal sling versus Burch surgery.

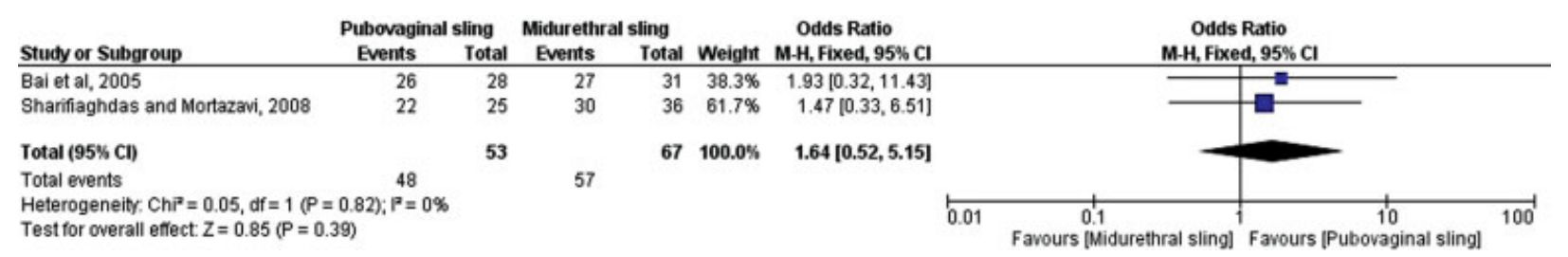

Fig. 6 Objective cure: Pubovaginal sling versus midurethral sling. 
assess subjective cure. ${ }^{27,32,37,39,41,46}$ All authors reported data on complications.

To assess objective cure, the authors used: the pad test, $^{29,33,34,36-40,42,43,45,47}$ stress test ${ }^{26-30,32-37,40,42-45}$ and urodynamic evaluation. $26,27,32,41$

To evaluate subjective cure, the authors used the following tools: satisfaction test, ${ }^{30,32,33,36-38}$ VAS, $^{26,30,33,34,37,40}$ and quality of life questionnaires, including the Incontinence Quality of Life questionnaire (I-QOL), ${ }^{27,35}$ ISI, ${ }^{28}$ Pelvic Floor Distress Inventory, Short Form-20 (PFDI-20), ${ }^{28}$ Pelvic Floor Impact Questionnaire Short Form-7 (PFIQ-7), ${ }^{28,47}$ PGII, ${ }^{28,43,47}$ Short Form 12 (SF-12), ${ }^{28}$ Pelvic Organ Prolapse/Urinary Incontinence Sexual Questionnaire Short Form (PISQ-12), ${ }^{28,39,47}$ Quality Of Life Assessment Questionnaire Concerning Urinary Incontinence (CONTILIFE), ${ }^{30,33}$ International Consultation Incontinence Modular Questionnaire-Female Lower Urinary Tract Symptoms (ICIQ-FLUTS), ${ }^{31}$ IIQ-7,,$^{29,32,34,37-39,41-43}$ UDI-6, ${ }^{29,32,34,37-39,41-43}$ UISS, ${ }^{34,37}$ Detrusor Instability Score (DIS), ${ }^{34,37}$ Medical Epidemiological and Social Aspects of Aging (MESA ${ }^{36}$ and King's Health Questionnaire (KHQ). ${ }^{40}$
After the meta-analysis of objective cure data, the conclusion was that there was a statistically significant difference between the surgical treatments with retropubic and transobturator sling favoring the retropubic device (OR, 1.27; 95\% CI, 1.05-1.54) - Fig. 7. The same conclusions were drawn regarding subjective cure (OR, 1.23; 95\% CI, 1.02-1.48) - Fig. 8 .

Regarding complications, the retropubic slings significantly caused a greater number of vascular lesions (OR, 2.96, 95\% CI, 1.41-6.24), hematoma (OR, 3.02, 95\% CI, 1.34-6.82), bladder perforation (OR, $5.45,95 \% \mathrm{CI}, 3.33-8.90)$, urinary retention for less than 6 weeks (OR, 2.00, 95\% CI, 1.45-2.77) and return to the operating room due to urinary retention (OR, 3.78, 95\% CI, 2.00-7.13). Surgical treatment of SUI using the transobturator sling, in turn, produced significantly more cases of all of the following: leg pain(OR, $0.18,95 \% \mathrm{CI}, 0.11-0.30)$, groin pain(OR, $0.17,95 \% \mathrm{CI}, 0.08-0.35$ ), neurological injury (OR, 0.48, 95\% CI, $0.27-0.87$ ) and vaginal perforation (OR, 0.24, 95\% CI, $0.14-$ 0.40 ). There was no significant difference between these procedures related to the following adverse events: blood loss, overactive bladder, surgical wound complications, unspecified pain, erosion, return to the operating room due to

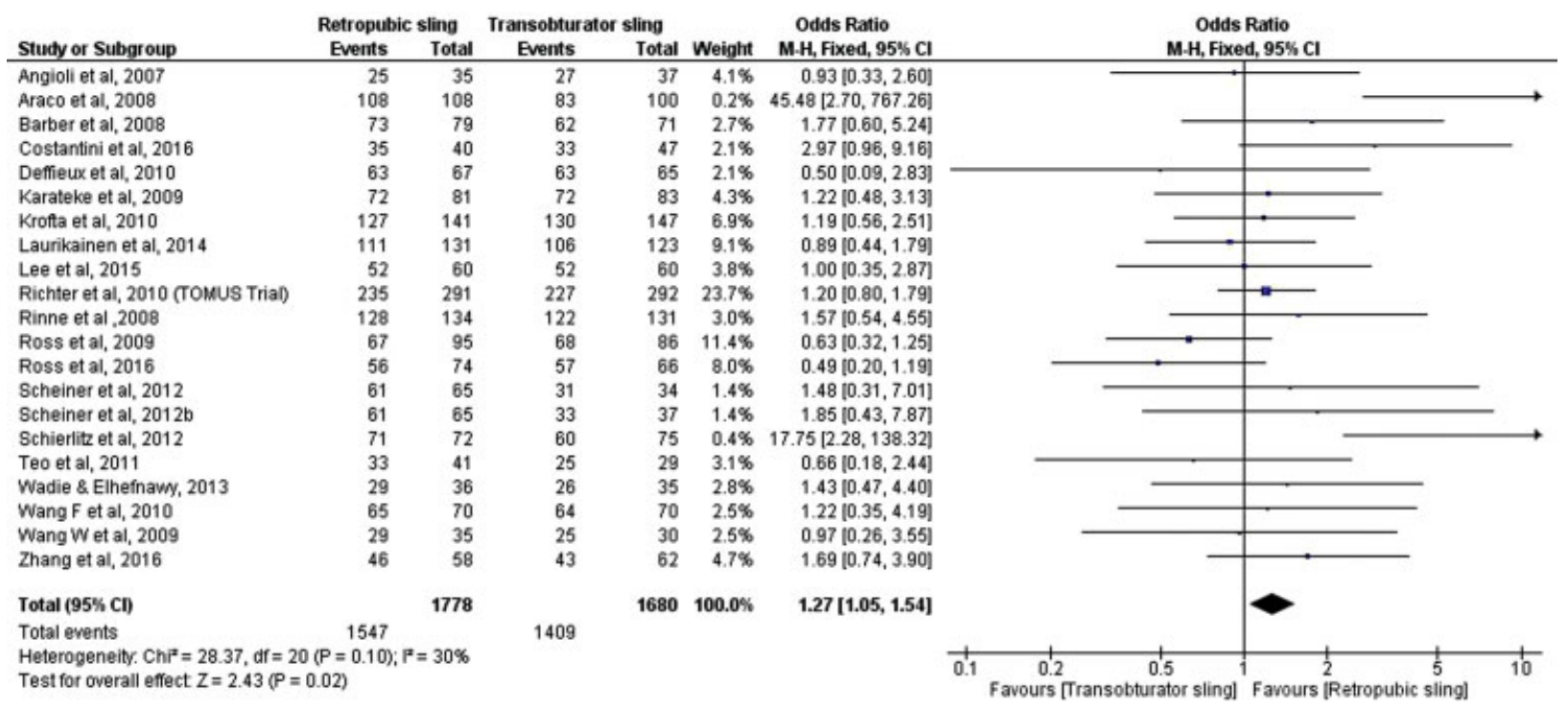

Fig. 7 Objective cure: Retropubic sling versus transobturator sling.

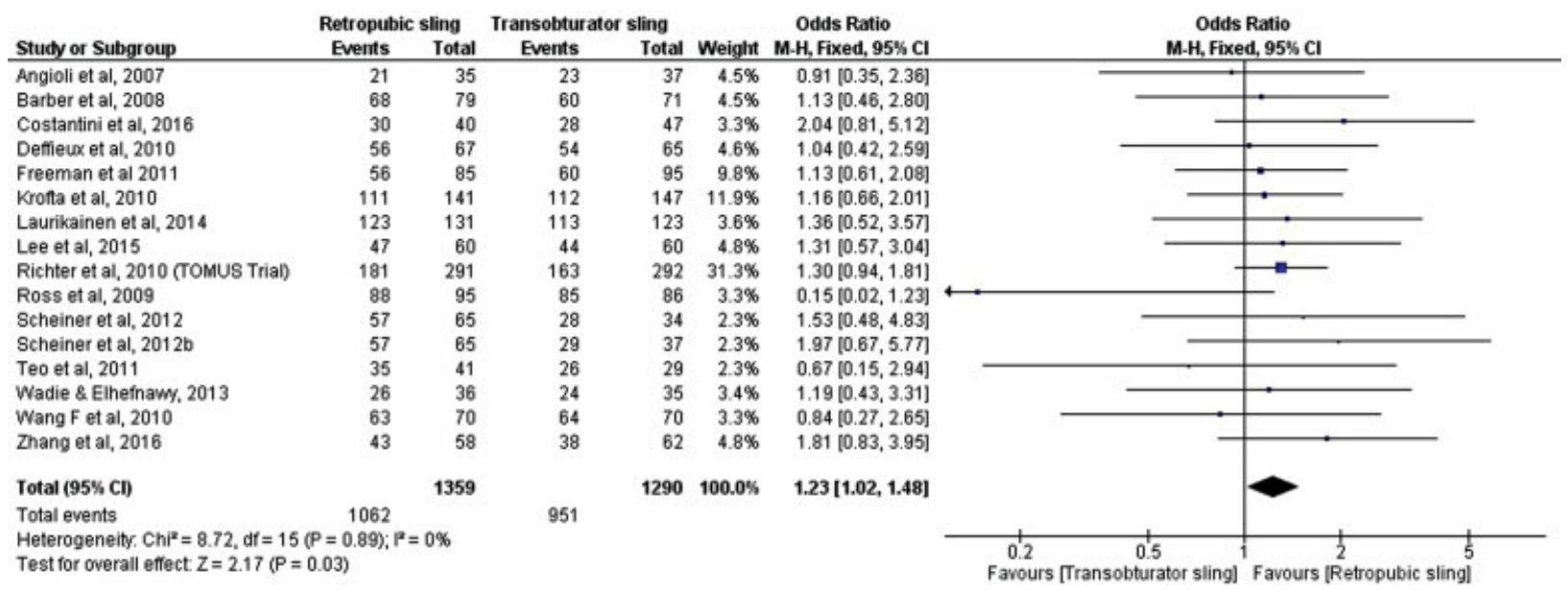

Fig. 8 Subjective cure: Retropubic sling versus transobturator sling. 
erosion, urinary tract infection, blood transfusion, urethral perforation, urinary retention lasting for longer than 6 weeks and de novo urgency.

\section{Outside-in Midurethral Transobturator Sling versus Inside-out Midurethral Transobturator Sling}

For this comparison, we found 5 studies totaling 719 patients, 360 in the TOT group and 359 in the TVT-O group. In one of the studies, the authors used an Aris TOT sling; ${ }^{48}$ TOT Monarc slings ${ }^{40,48-50}$ were used in the other studies. These slings were compared with TVT-O slings.

Of the studies found in this group of analysis, four showed results on objective cure. ${ }^{40,47,49,50}$ All of the studies presented data on subjective cure and adverse events.

To assess objective cure, the authors used: pad test, ${ }^{40,47,49}$ stress test ${ }^{40,50}$ and urodynamic evaluation. ${ }^{49,50}$

To assess subjective cure, the authors used: satisfaction test, ${ }^{47}$ VAS, ${ }^{40}$ and questionnaires on quality of life, including $\mathrm{KHQ}^{40,47}$ International Consultation on Incontinence Questionnaire-Short Form (ICIQ-SF), ${ }^{47}$ PGII, ${ }^{47}$ UDI-6 ${ }^{48}$ and IIQ-7. ${ }^{48}$

The meta-analysis showed no significant difference regarding objective cure in the comparison between TOT and TVT-O slings (OR, 0.78, 95\% CI, 0.45-1.35) - Fig. 9. For subjective cure, no significant difference was found in the meta-analysis either (OR, 0.83; 95\% CI, 0.58-1.18) - Fig. 10.

Regarding adverse events, we observed that TOT slings presented higher rates of vaginal perforation (OR, 3.31, 95\% CI, 1.44-7.61) and erosion (OR, 4.83, 95\% CI, 1.28-18.27). There was no significant difference between these procedures in terms of postoperative pain, urinary retention for more or less than 6 weeks, return to the operating room due to urinary retention, de novo urgency and leg pain. Overactive bladder, UTI and urethral perforation were reported in a single study, thus precluding a meta-analysis.

\section{Minisling versus Any Other Sling}

For this comparison, we found 8 studies totaling 993 patients, 502 in the minislings group and 491 in the comparison group. In three studies, the authors used the Miniarc minisling (American Medical Systems, Minnetonka, MN, USA), ${ }^{51,55,56}$ which was compared with the Advantage retropubic sling ${ }^{51}$ and the Monarc transobturator sling. ${ }^{55,56}$ One of the studies compared the Ophira minisling and the TOT Unitape (both made by Promedon, Cordoba, Argentina), ${ }^{52}$ while others compared the Contasure-Needleless (New Medical Technologies, Barcelona, Spain) minisling and endopelvic free anchor (EFA), ${ }^{53}$ and the Ophira minisling ${ }^{54}$ with the TVT-O. One study compared the TFS minisling (TFS Surgical, Adelaide, Australia) with the TOT I-STOP (CL Medical, Sainte Foys Les Lyon, France). ${ }^{57}$

Only one study ${ }^{51}$ failed to report objective cure. All studies showed results for subjective cure and adverse events.

To assess objective cure, the authors used the pad test ${ }^{52,57}$ and stress test. ${ }^{52-56}$

For subjective cure, the authors used the satisfaction test ${ }^{52}$ and quality of life questionnaires, including the $\mathrm{KHQ}^{51} \mathrm{I}-\mathrm{QOL},{ }^{52}$ UDI, ${ }^{52}$ International Consultation on Incontinence Questionnaire/ Urinary Incontinence Short Form (ICIQ-UIFS), ${ }^{53-55}$ International Consultation on Incontinence Questionnaire/ Overactive Bladder (ICIQ OAB), ${ }^{55}$ IIQ-7, ${ }^{55}$ PGII, ${ }^{53-56}$ UDI-6, ${ }^{56}$ Patient Global Impression Severity (PGI-S), ${ }^{56}$ and Patient Perception of Intensity of Urgency Scale (PPIUS). ${ }^{54}$

The meta-analysis showed no significant difference between minislings and other slings for objective cure (OR, 0.72; 95\% CI, 0.47-1.10) - Fig. 11. For subjective cure, we found a significant difference favoring other slings ( $\mathrm{OR}, 0.58,95 \% \mathrm{CI}$, 0.39-0.86) - Fig. 12.

Regarding the adverse events, the group that included other types of slings had a higher rate of groin pain (OR, 0.11 $95 \% \mathrm{CI}, 0.04-0.28$ ) and unspecified pain (OR, 0.20, 95\% CI, $0.07-0.61)$, noting that transobturator slings were used in

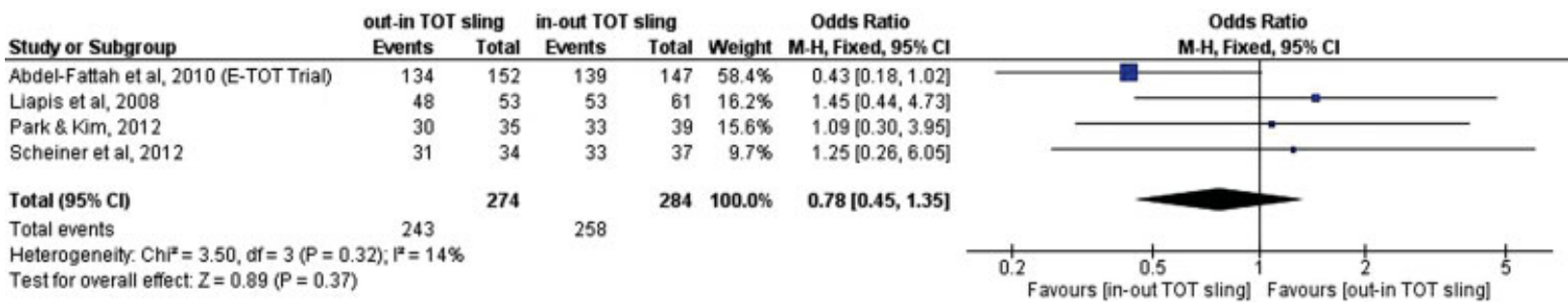

Fig. 9 Objective cure: outside-in transobturator sling versus inside-out transobturator sling.

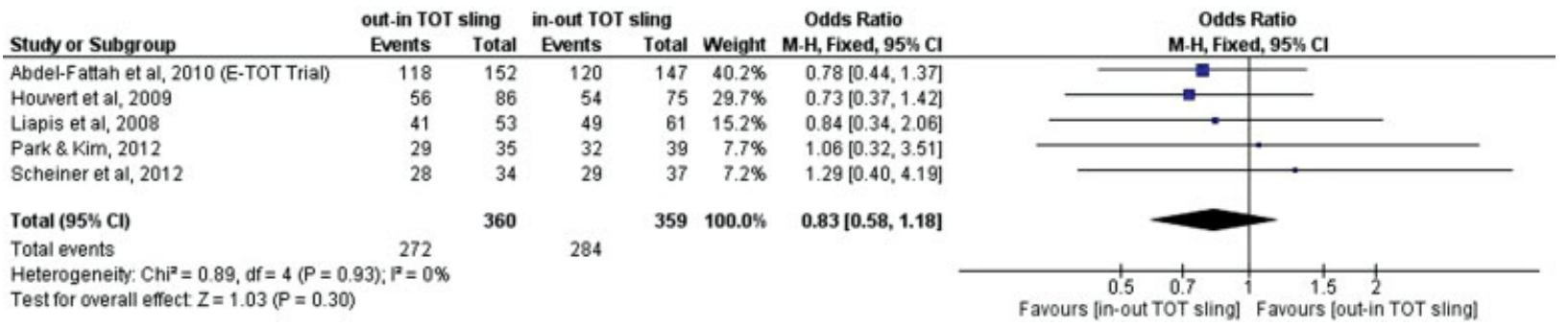

Fig. 10 Subjective cure: outside-in transobturator sling versus inside-out transobturator sling. 


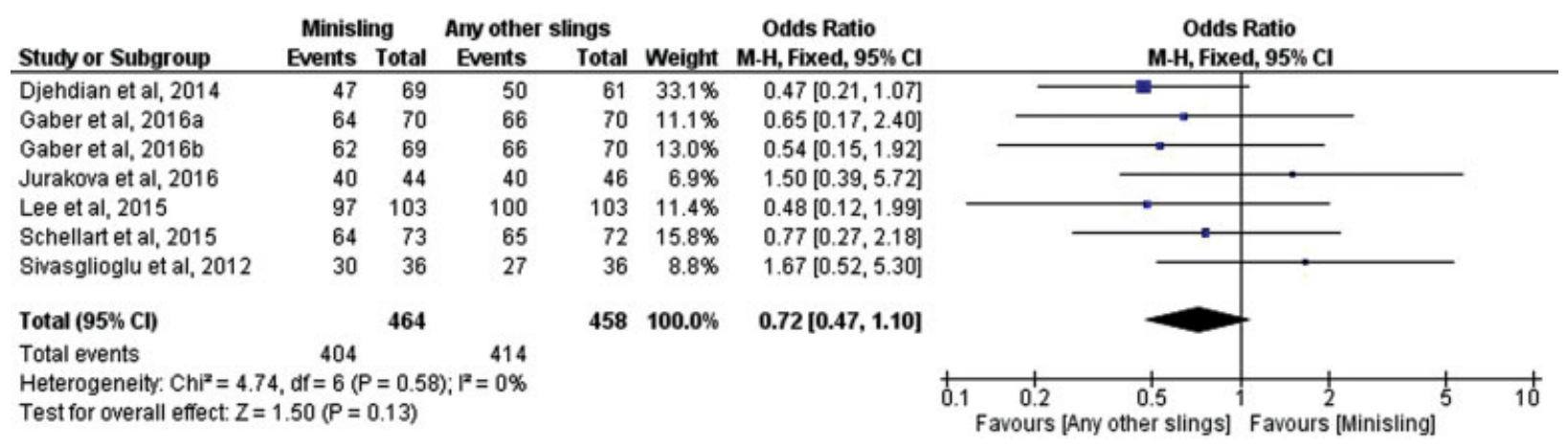

Fig. 11 Objective cure: Minisling versus any other sling.

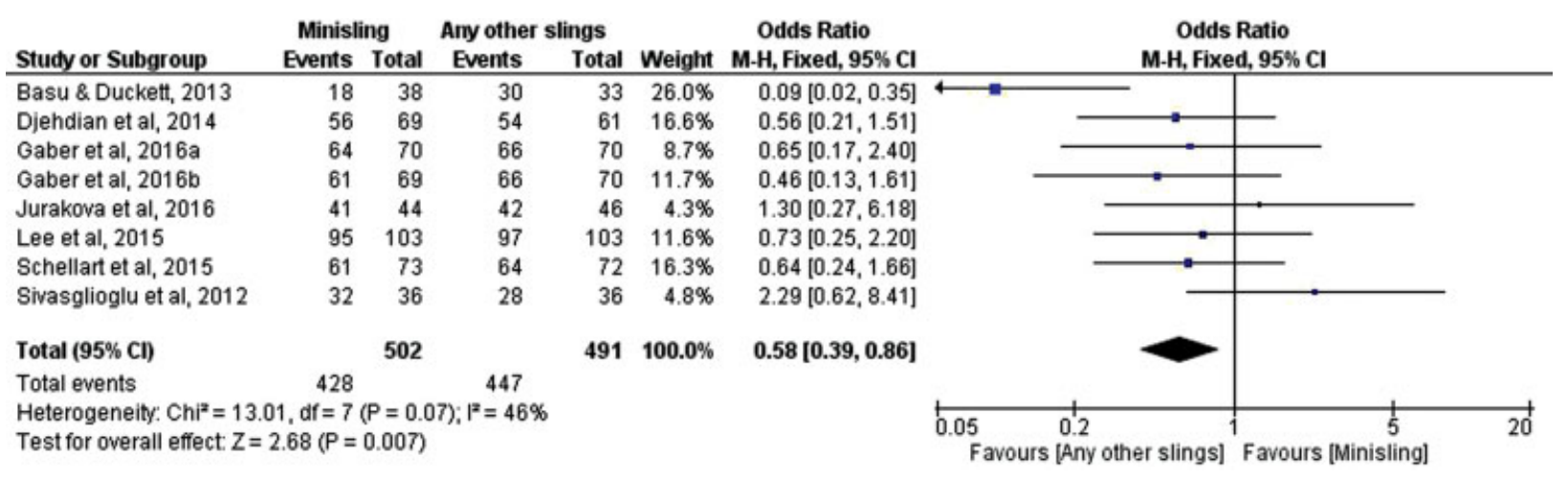

Fig. 12 Subjective cure: Minisling versus any other sling.

the studies that we analyzed for these variables. ${ }^{55-57}$ There was no significant difference between the groups for rates of overactive bladder, erosion, UTI, return to the operating room due to urinary retention, urinary retention for more or less than 6 weeks and de novo urgency.

The data on adverse events, leg pain, hematoma, return to the operating room due to erosion, blood loss, urethral perforation and vaginal perforation were all described in a single study, thus precluding a meta-analysis.

\section{Discussion}

Several techniques have been described for the surgical treatment of SUI. Burch retropubic colposuspension surgery, considered the gold standard in the treatment of this condition for decades, gave way to the pubovaginal sling, and later, to the retropubic synthetic midurethral sling, described in 1996 by Ulmsten et al, ${ }^{5}$ showing a very satisfactory success rate. Next, transobturator slings were introduced using both outside-in and inside-out techniques as described by Delorme, in $2001,{ }^{10}$ and de Leval, in $2003,{ }^{11}$ respectively, in an attempt to reduce adverse events, especially bladder perforation and visceral and vascular lesions. In 2006, a single incision sling was developed following a trend toward minimally invasive procedures to reduce the amount of synthetic material used and reduce the blind needle path, thus minimizing tissue damage and infections.

Due to the large number of articles found in the literature, we decided to select studies of high-scientific quality to perform our meta-analysis.
In our work, we selected articles comparing midurethral sling versus Burch colposuspension, pubovaginal sling versus Burch colposuspension, pubovaginal sling versus midurethral sling, retropubic midurethral sling versus transobturator midurethral sling, outside-in transobturator midurethral sling versus inside-out transobturator midurethral sling, and minisling versus any other slings. The group with the highest number of articles was the one that compared the retropubic midurethral sling versus transobturator, with 22 studies selected.

Our view is that some bias should be considered while analyzing the results of this meta-analysis. Several studies do not distinguish between patients with and without intrinsic sphincteric deficiency, patients with recurrent or untreated SUI, which hinders a more detailed analysis. Another important bias was surgery performed concomitantly with surgical treatment for SUI (vaginal and abdominal hysterectomy, correction of anterior and posterior wall prolapses, and correction of vaginal vault prolapse). Moreover, we do not always find data on the individual conditions of the patients (lung disease, diabetes, neuropathy, etc.). The various criteria used for objective cure are also a bias factor. In the studies selected for our meta-analysis, the cure was defined based on urodynamic evaluation, a stress test and/or pad test. This lack of uniformity can significantly affect results. The same can be said regarding subjective cure, since some studies used quality of life questionnaires, while others only applied satisfaction surveys to define this outcome. Many of the studies analyzed are multicentric, with patients being operated on by different surgeons with varying experience degrees. It is known that surgeon 
experience is a determining factor for the success of a surgical procedure, as well as the occurrence of complications. ${ }^{62,63}$

One of the factors that could be considered when choosing the treatment is the cost-benefit ratio. However, very few studies analyzed this variable. Among the studies selected for our meta-analysis, only one ${ }^{19}$ included such an evaluation.

As for the comparison of techniques in the analyzed studies, we verified that there was no significant difference regarding objective and subjective cure between midurethral sling and Burch colposuspension, although the latter presented more complications in terms of surgical wounds and UTI. With respect to midurethral slings, there were higher rates of bladder perforation and vaginal erosion, noting that comparisons were made with retropubic slings.

However, when comparing the pubovaginal sling and Burch surgery, the former was superior, in relation to objective and subjective cure, but presented a higher rate of return to the operating room due to urinary retention, which corroborates the literature results that pubovaginal slings are more retentionist. ${ }^{64,65}$ We must point out that whenever the patient has indication for gynecological surgery using the abdominal route combined with stress urinary incontinence, Burch colposuspension is an adequate option.

In the comparison of pubovaginal sling versus midurethral sling, both presented high rates of objective cure but no significant difference between the two.

Comparing retropubic and transobturator slings, we observed that the retropubic devices were significantly superior, in relation to objective and subjective cure, despite the small difference. One possible explanation for this result is the more vertical positioning of the tape from the urethral axis in the retropubic route, unlike the horizontal position used via the transobturator route. ${ }^{66}$ This hypothesis would also explain the greater effectiveness of the retropubic technique over the transobturator in cases of SUI with IDS $^{67}$ as well as the better long-term results favorable to retropubic sling. ${ }^{29}$ With regard to adverse events, we found a greater number of cases of bladder perforation, urinary retention, return to the operating room due to urinary retention, vascular injury and hematoma with retropubic slings. These last complications occur due to the blind passage of the needle through the Retzius space, which can lead to injury of veins and arteries, and ultimately bleeding and hematoma, as found in an ultrasound investigation immediately after surgery. ${ }^{68}$ The higher rate of urinary retention in retropubic slings is probably due to the more vertical position of the tape compared with the transobturator sling, ${ }^{28,69,70}$ as previously mentioned.

The transobturator sling, on the other hand, presented significantly more cases of leg pain, groin pain, neurological lesions and vaginal perforations.

Although the retropubic sling had significantly higher cure rates compared with the transobturator, the difference was small. The choice should therefore be based on the patient's history and individual characteristics, leaving the surgeon to decide the best route based on the possibility of complications, and his or her experience and preference, sharing the decision with the patient.
The TOT, when compared with TVT-O, did not show significant differences regarding objective and subjective cure. However, there was more vaginal perforation and erosion in the TOT group, which probably occurs because the needle passes closer to the vaginal sulcus in this technique. $^{40}$

Compared with other slings, minislings did not show significant difference regarding objective cure; however, there was a significant difference regarding subjective cure, favorable to other slings. For adverse events, the group of other slings had a higher rate of groin pain and unspecified pain, which was only seen in transobturator slings.

In several comparisons, our meta-analysis failed to demonstrate significant differences regarding objective cure, subjective cure, and adverse effects among the various techniques, a result also obtained in a Cochrane metaanalysis published in $2015 .^{71}$ Novara et al (2010), ${ }^{72}$ in turn, found superiority of retropubic slings compared with transobturator slings with respect to objective cure, and no difference between techniques related to subjective cure.

Our meta-analysis does not offer final conclusions about the effectiveness of the various techniques for intrinsic sphincteric deficiency, since most of the included studies failed to analyze this condition alone.

\section{Conclusion}

Our systematic review, followed by the meta-analysis, included studies of high methodological quality aiming at comparing the various techniques available for surgical correction of SUI. According to our results, pubovaginal slings demonstrated better objective and subjective results when compared with Burch colposuspension surgery, but pubovaginal slings exhibited more retention, often resulting in a return to the operating room. When we compared the retropubic and transobturator slings, we observed the superiority of the retropubic sling objectively and subjectively but a greater number of adverse events. In the comparative analysis between minislings and other slings, superiority was noted for the latter in the subjective aspect. When comparing the midurethral slings with Burch colposuspension surgery, t no statistically significant difference in relation to objective or subjective cure was found. When comparing pubovaginal and midurethral slings, there was also no significant difference in relation to the objective cure. Likewise, no statistically significant difference was observed between inside-out and outside-in transobturator slings for both objective and subjective cure. Based on the above, we believe that the choice of technique should be aligned with several factors, such as abdominal or vaginal surgeries performed concomitantly, the surgeon's experience, the patient's prior surgeries, adverse events and availability of materials.

\section{Conflicts of Interest}

The authors have no conflicts of interest to declare. 


\section{References}

1 Abrams P, Cardozo L, Fall M, et al; Standardisation Sub-Committee of the International Continence Society. The standardisation of terminology in lower urinary tract function: report from the standardisation sub-committee of the International Continence Society. Urology 2003;61(01):37-49. Doi: 10.1016/S0090-4295(02)02243-4

2 Irwin DE, Milsom I, Hunskaar S, et al. Population-based survey of urinary incontinence, overactive bladder, and other lower urinary tract symptoms in five countries: results of the EPIC study. Eur Urol 2006;50(06):1306-1314, discussion 1314-1315. Doi: 10.1016/j. eururo.2006.09.019

3 Botlero R, Urquhart DM, Davis SR, Bell RJ. Prevalence and incidence of urinary incontinence in women: review of the literature and investigation of methodological issues. Int J Urol 2008;15 (03):230-234. Doi: 10.1111/j.1442-2042.2007.01976.x

4 Coyne KS, Sexton CC, Thompson CL, et al. The prevalence of lower urinary tract symptoms (LUTS) in the USA, the UK and Sweden: results from the Epidemiology of LUTS (EpiLUTS) study. BJU Int 2009;104(03):352-360. Doi: 10.1111/j.1464-410X.2009.08427.x

5 Ulmsten U, Henriksson L, Johnson P, Varhos G. An ambulatory surgical procedure under local anesthesia for treatment of female urinary incontinence. Int Urogynecol J Pelvic Floor Dysfunct 1996;7(02):81-85, discussion 85-86. Doi: 10.1007/BF01902378

6 Celebi I, Güngördük K, Ark C, Akyol A. Results of the tension-free vaginal tape procedure for treatment of female stress urinary incontinence: a 5-year follow-up study. Arch Gynecol Obstet 2009;279(04):463-467. Doi: 10.1007/s00404-008-0805-2

7 Olsson I, Abrahamsson AK, Kroon UB. Long-term efficacy of the tension-free vaginal tape procedure for the treatment of urinary incontinence: a retrospective follow-up 11.5 years post-operatively. Int Urogynecol J Pelvic Floor Dysfunct 2010;21(06): 679-683. Doi: 10.1007/s00192-009-1083-7

8 Karram MM, Segal JL, Vassallo BJ, Kleeman SD. Complications and untoward effects of the tension-free vaginal tape procedure. Obstet Gynecol 2003;101(5 Pt 1):929-932. Doi: 10.1016/S00297844(03)00122-4

9 Sander P, Sørensen F, Lose G. Does the tension-free vaginal tape procedure (TVT) affect the voiding function over time? Pressureflow studies 1 year and 3(1/2) years after TVT. Neurourol Urodyn 2007;26(07):995-997. Doi: 10.1002/nau.20401

10 Delorme E. [Transobturator urethral suspension: mini-invasive procedure in the treatment of stress urinary incontinence in women]. Prog Urol 2001;11(06):1306-1313

11 de Leval J. Novel surgical technique for the treatment of female stress urinary incontinence: transobturator vaginal tape inside-out. Eur Urol 2003;44(06):724-730. Doi: 10.1016/j.eururo.2003.09.003

12 Hazewinkel MH, Hinoul P, Roovers JP. Persistent groin pain following a trans-obturator sling procedure for stress urinary incontinence: a diagnostic and therapeutic challenge. Int Urogynecol J Pelvic Floor Dysfunct 2009;20(03):363-365. Doi: 10.1007/ s00192-008-0714-8

13 Mostafa A, Lim CP, Hopper L, Madhuvrata P, Abdel-Fattah M. Single-incision mini-slings versus standard midurethral slings in surgical management of female stress urinary incontinence: an updated systematic review and meta-analysis of effectiveness and complications. Eur Urol 2014;65(02):402-427. Doi: 10.1016/ j.eururo.2013.08.032

14 Jadad AR, Moore RA, Carroll D, et al. Assessing the quality of reports of randomized clinical trials: is blinding necessary? Control Clin Trials 1996;17(01):1-12. Doi: 10.1016/0197-2456 (95)00134-4

15 Bai SW, Sohn WH, Chung DJ, Park JH, Kim SK. Comparison of the efficacy of Burch colposuspension, pubovaginal sling, and tensionfree vaginal tape for stress urinary incontinence. Int J Gynaecol Obstet 2005;91(03):246-251. Doi: 10.1016/j.ijgo.2005.08.023

16 Jelovsek JE, Barber MD, Karram MM, Walters MD, Paraiso MFR. Randomised trial of laparoscopic Burch colposuspension versus tension-free vaginal tape: long-term follow up. BJOG 2008;115(02): 219-225, discussion 225. Doi: 10.1111/j.1471-0528.2007.01592.x

17 Liapis A, Bakas P, Creatsas G. Burch colposuspension and tensionfree vaginal tape in the management of stress urinary incontinence in women. Eur Urol 2002;41(04):469-473

18 Paraiso MFR, Walters MD, Karram MM, Barber MD. Laparoscopic Burch colposuspension versus tension-free vaginal tape: a randomized trial. Obstet Gynecol 2004;104(06):1249-1258. Doi: 10.1097/01.AOG.0000146290.10472.b3

19 Persson J, Teleman P, Etén-Bergquist C, Wølner-Hanssen P. Costanalyzes based on a prospective, randomized study comparing laparoscopic colposuspension with a tension-free vaginal tape procedure. Acta Obstet Gynecol Scand 2002;81(11):1066-1073. Doi: 10.1034/j.1600-0412.2002.811112.x

20 Ward KL, Hilton P; UK and Ireland TVT Trial Group. Tension-free vaginal tape versus colposuspension for primary urodynamic stress incontinence: 5-year follow up. BJOG 2008;115(02): 226-233. Doi: 10.1111/j.1471-0528.2007.01548.x

21 Valpas A, Ala-Nissilä S, Tomas E, Nilsson CG. TVT versus laparoscopic mesh colposuspension: 5-year follow-up results of a randomized clinical trial. Int Urogynecol J Pelvic Floor Dysfunct 2015;26(01):57-63. Doi: 10.1007/s00192-014-2454-2

22 Albo ME, Richter HE, Brubaker L, et al; Urinary Incontinence Treatment Network. Burch colposuspension versus fascial sling to reduce urinary stress incontinence. N Engl J Med 2007;356(21): 2143-2155. Doi: 10.1056/NEJMoa070416

23 Culligan PJ, Goldberg RP, Sand PK. A randomized controlled trial comparing a modified Burch procedure and a suburethral sling: long-term follow-up. Int Urogynecol J Pelvic Floor Dysfunct 2003; 14(04):229-233, discussion 233. Doi: 10.1007/s00192-003$1057-0$

24 Guerrero KL, Emery SJ, Wareham K, Ismail S, Watkins A, Lucas MG. A randomised controlled trial comparing TVT, Pelvicol and autologous fascial slings for the treatment of stress urinary incontinence in women. BJOG 2010;117(12):1493-1502. Doi: 10.1111/ j.1471-0528.2010.02696.x

25 Sharifiaghdas F, Mortazavi N. Tension-free vaginal tape and autologous rectus fascia pubovaginal sling for the treatment of urinary stress incontinence: a medium-term follow-up. Med Princ Pract 2008;17(03):209-214. Doi: 10.1159/000117794

26 Angioli R, Plotti F, Muzii L, Montera R, Panici PB, Zullo MA. Tensionfree vaginal tape versus transobturator suburethral tape: five-year follow-up results of a prospective, randomised trial. Eur Urol 2010; 58(05):671-677. Doi: 10.1016/j.eururo.2010.08.004

27 Araco F, Gravante G, Sorge R, et al. TVT-O vs TVT: a randomized trial in patients with different degrees of urinary stress incontinence. Int Urogynecol J Pelvic Floor Dysfunct 2008;19(07): 917-926. Doi: 10.1007/s00192-007-0554-y

28 Barber MD, Kleeman S, Karram MM, et al. Transobturator tape compared with tension-free vaginal tape for the treatment of stress urinary incontinence: a randomized controlled trial. Obstet Gynecol 2008;111(03):611-621. Doi: 10.1097/AOG.0b013e318162f22e

29 Costantini E, Kocjancic E, Lazzeri M, et al. Long-term efficacy of the trans-obturator and retropubic mid-urethral slings for stress urinary incontinence: update from a randomized clinical trial. World J Urol 2016;34(04):585-593. Doi: 10.1007/s00345-015$1651-z$

30 Deffieux X, Daher N, Mansoor A, Debodinance P, Muhlstein J, Fernandez H. Transobturator TVT-O versus retropubic TVT: results of a multicenter randomized controlled trial at 24 months follow-up. Int Urogynecol J Pelvic Floor Dysfunct 2010;21(11): 1337-1345. Doi: 10.1007/s00192-010-1196-z

31 Freeman R, Holmes D, Hillard T, et al. What patients think: patientreported outcomes of retropubic versus trans-obturator mid-urethral slings for urodynamic stress incontinence-a multi-centre randomised controlled trial. Int Urogynecol J Pelvic Floor Dysfunct 2011;22(03):279-286. Doi: 10.1007/s00192-010-1343-6 
32 Karateke A, Haliloglu B, Cam C, Sakalli M. Comparison of TVT and TVT-O in patients with stress urinary incontinence: short-term cure rates and factors influencing the outcome. A prospective randomised study. Aust N Z J Obstet Gynaecol 2009;49(01): 99-105. Doi: 10.1111/j.1479-828X.2009.00957.x

33 Krofta L, Feyereisl J, Otcenásek M, Velebil P, Kasíková E, Krcmár M. TVT and TVT-O for surgical treatment of primary stress urinary incontinence: prospective randomized trial. Int Urogynecol J Pelvic Floor Dysfunct 2010;21(02):141-148. Doi: 10.1007/s00192-0091027-2

34 Laurikainen E, Valpas A, Aukee P, et al. Five-year results of a randomized trial comparing retropubic and transobturator midurethral slings for stress incontinence. Eur Urol 2014;65(06): 1109-1114. Doi: 10.1016/j.eururo.2014.01.031

35 Lee KS, Han DH, Choi YS, et al. A prospective trial comparing tension-free vaginal tape and transobturator vaginal tape insideout for the surgical treatment of female stress urinary incontinence: 1-year followup. J Urol 2007;177(01):214-218. Doi: 10.1016/j.juro.2006.08.063

36 Richter HE, Albo ME, Zyczynski HM, et al; Urinary Incontinence Treatment Network. Retropubic versus transobturator midurethral slings for stress incontinence. N Engl J Med 2010;362(22): 2066-2076. Doi: 10.1056/NEJMoa0912658

37 Rinne K, Laurikainen E, Kivelä A, et al. A randomized trial comparing TVT with TVT-O: 12-month results. Int Urogynecol J Pelvic Floor Dysfunct 2008;19(08):1049-1054. Doi: 10.1007/ s00192-008-0581-3

38 Ross S, Robert M, Swaby C, et al. Transobturator tape compared with tension-free vaginal tape for stress incontinence: a randomized controlled trial. Obstet Gynecol 2009;114(06):1287-1294. Doi: 10.1097/AOG.0b013e3181c2a151

39 Ross S, Tang S, Eliasziw M, et al. Transobturator tape versus retropubic tension-free vaginal tape for stress urinary incontinence: 5-year safety and effectiveness outcomes following a randomised trial. Int Urogynecol J Pelvic Floor Dysfunct 2016; 27(06):879-886. Doi: 10.1007/s00192-015-2902-7

40 Scheiner DA, Betschart C, Wiederkehr S, Seifert B, Fink D, Perucchini $D$. Twelve months effect on voiding function of retropubic compared with outside-in and inside-out transobturator midurethral slings. Int Urogynecol J Pelvic Floor Dysfunct 2012;23(02): 197-206. Doi: 10.1007/s00192-011-1543-8

41 Schierlitz L, Dwyer PL, Rosamilia A, et al. Three-year follow-up of tension-free vaginal tape compared with transobturator tape in women with stress urinary incontinence and intrinsic sphincter deficiency. Obstet Gynecol 2012;119(2 Pt 1):321-327. Doi: 10.1097/AOG.0b013e31823dfc73

42 Teo R, Moran P, Mayne C, Tincello D. Randomized trial of tensionfree vaginal tape and tension-free vaginal tape-obturator for urodynamic stress incontinence in women. J Urol 2011;185 (04):1350-1355. Doi: 10.1016/j.juro.2010.11.064

43 Wadie BS, El-Hefnawy AS. TVT versus TOT, 2-year prospective randomized study. World J Urol 2013;31(03):645-649. Doi: 10.1007/s00345-012-0956-4

44 Wang F, Song Y, Huang H. Prospective randomized trial of TVT and TOT as primary treatment for female stress urinary incontinence with or without pelvic organ prolapse in Southeast China. Arch Gynecol Obstet 2010;281(02):279-286. Doi: 10.1007/s00404-009-1098-9

45 Wang W, Zhu L, Lang J. Transobturator tape procedure versus tension-free vaginal tape for treatment of stress urinary incontinence. Int J Gynaecol Obstet 2009;104(02):113-116. Doi: 10.1016/j.ijgo.2008.09.013

46 Zhang Z, Zhu L, Xu T, Lang J. Retropubic tension-free vaginal tape and inside-out transobturator tape: a long-term randomized trial. Int Urogynecol J Pelvic Floor Dysfunct 2016;27(01):103-111. Doi: 10.1007/s00192-015-2798-2

47 Abdel-Fattah M, Ramsay I, Pringle S, et al. Randomised prospective single-blinded study comparing 'inside-out' versus 'outsidein' transobturator tapes in the management of urodynamic stress incontinence: 1-year outcomes from the E-TOT study. BJOG 2010; 117(07):870-878. Doi: 10.1111/j.1471-0528.2010.02544.x

48 Houwert RM, Renes-Zijl C, Vos MC, Vervest HAM. TVT-O versus Monarc after a 2-4-year follow-up: a prospective comparative study. Int Urogynecol J Pelvic Floor Dysfunct 2009;20(11):1327-1333. Doi: 10.1007/s00192-009-0943-5

49 Liapis A, Bakas P, Creatsas G. Monarc vs TVT-O for the treatment of primary stress incontinence: a randomized study. Int Urogynecol J Pelvic Floor Dysfunct 2008;19(02):185-190. Doi: 10.1007/ s00192-007-0432-7

50 Park YJ, Kim DY. Randomized controlled study of MONARC $®$ vs. tension-free vaginal tape obturator (TVT-O®) in the treatment of female urinary incontinence: comparison of 3-year cure rates. Korean JUrol 2012;53(04):258-262.Doi: 10.4111/kju.2012.53.4.258

51 Basu M, Duckett J. Three-year results from a randomised trial of a retropubic mid-urethral sling versus the Miniarc single incision sling for stress urinary incontinence. Int Urogynecol J Pelvic Floor Dysfunct 2013;24(12):2059-2064. Doi: 10.1007/s00192-013-2125-8

52 Djehdian LM, Araujo MP, Takano CC, et al. Transobturator sling compared with single-incision mini-sling for the treatment of stress urinary incontinence: a randomized controlled trial. Obstet Gynecol 2014;123(03):553-561. Doi: 10.1097/AOG.0000000000000148

53 Gaber ME, Borg T, Samour H, Nawara M, Reda A. Two new minislings compared with transobturator tension-free vaginal tape for treatment of stress urinary incontinence: A 1-year follow-up randomized controlled trial. J Obstet Gynaecol Res 2016;42 (12):1773-1781. Doi: $10.1111 /$ jog.13143

54 Jurakova M, Huser M, Belkov I, et al. Prospective randomized comparison of the transobturator mid-urethral sling with the single-incision sling among women with stress urinary incontinence: 1-year follow-up study. Int Urogynecol J Pelvic Floor Dysfunct 2016;27(05):791-796. Doi: 10.1007/s00192-015-2895-2

55 Lee JK, Rosamilia A, Dwyer PL, Lim YN, Muller R. Randomized trial of a single incision versus an outside-in transobturator midurethral sling in women with stress urinary incontinence: 12 month results. Am J Obstet Gynecol 2015;213(01):35.e1-35.e9. Doi: 10.1016/j.ajog.2015.01.040

56 Schellart RP, Oude Rengerink K, Van der Aa F, et al. A randomised comparison of single-incision versus traditional transobturator midurethral sling in women with stress urinary incontinence: results of a 24-month follow-up. Int Urogynecol J Pelvic Floor Dysfunct 2016;27(06):871-877. Doi: 10.1007/s00192-015-2898-z

57 Sivaslioglu AA, Unlubilgin E, Aydogmus S, Keskin L, Dolen I. A prospective randomized controlled trial of the transobturator tape and tissue fixation mini-sling in patients with stress urinary incontinence: 5-year results. J Urol 2012;188(01):194-199. Doi: 10.1016/j.juro.2012.02.2564

58 Borestein M, Hedges LV, Higgins JP, Rothstein HR. Introduction to Meta-Analysis. Hoboken, NJ: John Wiley \& Sons; 2009

59 DerSimonian R, Laird N. Meta-analysis in clinical trials. Control Clin Trials 1986;7(03):177-188. Doi: 10.1016/0197-2456(86) 90046-2

60 Higgins JP, Thompson SG. Quantifying heterogeneity in a metaanalysis. Stat Med 2002;21(11):1539-1558. Doi: 10.1002/sim.1186

61 Sutton AJ, Abrams KR, Jones DR, Sheldon TA, Song F. Methods for Meta-Analysis in Medical Research. Hoboken, NJ: John Wiley \& Sons; 2000

62 Haab F, Sananes S, Amarenco G, et al. Results of the tension-free vaginal tape procedure for the treatment of type II stress urinary incontinence at a minimum followup of 1 year. J Urol 2001;165 (01):159-162. Doi: 10.1097/00005392-200101000-00038

63 Lebret T, Lugagne PM, Hervé JM, et al. Evaluation of tension-free vaginal tape procedure. Its safety and efficacy in the treatment of female stress urinary incontinence during the learning phase. Eur Urol 2001;40(05):543-547

64 Black NA, Downs SH. The effectiveness of surgery for stress incontinence in women: a systematic review. Br J Urol 1996;78 (04):497-510. Doi: 10.1046/j.1464-410X.1996.01422.x 
65 Jarvis GJ. Surgery for genuine stress incontinence. Br J Obstet Gynaecol 1994;101(05):371-374. Doi: 10.1111/j.1471-0528.1994.tb11907.x

66 Long CY, Hsu CS, Lo TS, Liu CM, Chen YH, Tsai EM. Ultrasonographic assessment of tape location following tension-free vaginal tape and transobturator tape procedure. Acta Obstet Gynecol Scand 2008;87(01):116-121. Doi: 10.1080/00016340701797765

67 Ford AA, Ogah JA. Retropubic or transobturator mid-urethral slings for intrinsic sphincter deficiency-related stress urinary incontinence in women: a systematic review and meta-analysis. Int Urogynecol J Pelvic Floor Dysfunct 2016;27(01):19-28. Doi: 10.1007/s00192-015-2797-3

68 Tseng LH, Wang AC, Lin YH, Li SJ, Ko YJ. Randomized comparison of the suprapubic arc sling procedure vs tension-free vaginal taping for stress incontinent women. Int Urogynecol J Pelvic Floor Dysfunct 2005;16(03):230-235. Doi: 10.1007/s00192-004-1248-3

69 Novara G, Galfano A, Boscolo-Berto R, et al. Complication rates of tension-free midurethral slings in the treatment of female stress urinary incontinence: a systematic review and meta-analysis of randomized controlled trials comparing tension-free midurethral tapes to other surgical procedures and different devices. Eur Urol 2008;53(02):288-308. Doi: 10.1016/j.eururo.2007.10.073

70 Whiteside JL, Walters MD. Anatomy of the obturator region: relations to a trans-obturator sling. Int Urogynecol J Pelvic Floor Dysfunct 2004;15(04):223-226. Doi: 10.1007/s00192004-1143-y

71 Ford AA, Rogerson L, Cody JD, Ogah J. Mid-urethral sling operations for stress urinary incontinence in women. Cochrane Database Syst Rev 2015;(07):CD006375. Doi: 10.1002/14651858. CD006375.pub3

72 Novara G, Artibani W, Barber MD, et al. Updated systematic review and meta-analysis of the comparative data on colposuspensions, pubovaginal slings, and midurethral tapes in the surgical treatment of female stress urinary incontinence. Eur Urol 2010;58(02):218-238. Doi: 10.1016/j.eururo.2010.04.022 